\title{
A Non-denial Denial: A Study to Find Evidence That Donald Trump Is Changing the Perception of the Media
}

\author{
Brandy Walker ${ }^{1 *}$
}

\begin{abstract}
\section{Keywords}

Media Ethics — Donald Trump — Fake News - Twitter

${ }^{1}$ Mayborn School of Journalism, University of North Texas

*Faculty Mentor: Dr. Tom Miles
\end{abstract}

How is Donald Trump's accusations of fake news changing readers and viewer's perspective of the media? During the 2016 presidential elections, Donald Trump began to make public statements that discredit how journalists report the news. In this paper, I will examine the ways in which the integrity and accuracy of news reporting have been challenged. I will begin by first establishing what journalistic values and ethics are. Next, I will describe historical parallels beginning in the nineteenth century with the birth of yellow journalism, the 20th century with President Nixon, and in the 21st century with the introduction of citizen journalism. Lastly, I will explore the emergence of a new type of media and learning how people get their news. A preliminary conclusion is that Americans, in general, have a growing mistrust of the media The conclusions also show that both Trump and Nixon, both dealing with a significant White House crisis, draw upon this mistrust and use it to attack the press in an attempt to discredit reporters and deflect blame from themselves. In both cases, however, there is evidence that coverage of a White House crisis reaffirms the "watchdog" role of the news media, but this relationship is strongly conditioned by partisan affiliation. Trump is able to play on the public's levels of uncertainty and political polarization to advantage himself by makinf the media look dishonest.

\section{Contents}

\section{Introduction}

1 Freedom of the Press and Ethical Standards 2

1.1 Ethical Standards for Media Reporting . . . . . . 2

2 Conflicts with Ethical Reporting 2

2.1 Yellow Journalism . . . . . . . . . . . . . . . 2

2.2 Checkbook Journalism . . . . . . . . . . . . . . 2

2.3 Citizen Journalism . . . . . . . . . . . . . . 3

2.4 The Colbert Effect . . . . . . . . . . . . . 3

2.5 The Rise of Twitter . . . . . . . . . . . . . . 3

3 Analysis

3.1 Nixon and Trump . . . . . . . . . . . . . . 4

3.2 Examples of Nixon and Trump Statements ... . 4

4 Conclusion

References

\section{Introduction}

There is substantial debate over what effect, if any, Donald Trump is making on the perception of news. In the past, there has been a pattern of presidents finding the media to be unfavorable. They would sometimes criticize the media, but never with such blatancy as President Trump. Journalists have found themselves under a great deal of scrutiny from Trump since the 2016 presidential campaign. He has made his opinion of the media publicly known by making verbal insults and ongoing tweets.

The purpose of this rhetoric is still unknown, and only time will tell. But, it does lead some to speculate that there may be some type of hidden agenda in his attempts to discredit the media. When addressing this topic, it is important to know and understand the core values and principles that the media believes in. Ethics is the foundation that journalists stand on, and they learn this early on in their careers.

This paper analyzes the changing role of the media and the rise of "citizen journalism." I trace the historical parallels that exist between Nixon's and Trump's treatments of the media. 5 I find that, in both cases, skepticism of the media tended to decline during 


\section{Freedom of the Press and Ethical Standards}

The Constitution of the United States highlights the importance of establishing a checks and balance system. This is to ensure that no governmental branch has too much power. The First Amendment goes a step further by guaranteeing freedom of speech and freedom of the press. Understanding the First Amendment is crucial when determining the role of the media. Congress shall make no law respecting an establishment of religion, or prohibiting the free exercise thereof; or abridging the freedom of speech, or of the press; or the right of the people peaceably to assemble, and to petition the Government for a redress of grievances (U.S. Constitution, Amendment I).

Freedom of speech is beneficial for society because citizens are entitled to know the truth. When taking this into consideration, it is important to note that the truth can be perceived in diverse ways, and there are times when discerning what the truth is, can get a little tricky. Despite this, the truth prevails. There have been times in American history when the media has had to make some courageous choices. Serving in a watchdog capacity tends to ruffle some feathers from time to time. This risk, however, should not interfere with solid news reporting. A good example of this, was during the President Nixon era, and we are also seeing it displayed in the media now with the Trump administration.

\subsection{Ethical Standards for Media Reporting}

Over time, there have been attempts made to determine exactly what the responsibilities of the media are. The Society of Professional Journalists maps out a clear and concise picture of the ethical ways that a journalist should approach reporting the news. They place their focus on four main principles. First, you must seek the truth and report it. Ethical journalism should be accurate and fair. Journalists should be courageous in gathering, reporting, and interpreting information. We live in a society where information in constantly being shared. When seeking out the truth, journalists should always fact check and verify their news sources.

Second, you must make an effort to minimize harm. Ethical journalism treats sources, subjects, colleagues, and members of the public as human beings deserving respect. There are some occasions when a journalist must decide whether or not to report a news story. It's important to remember that all news is not news. Having the ability to make a distinction between what is newsworthy and what is not is imperative for all journalists. Third, you must act independently. The highest and primary obligation of ethical journalism is to serve the public. When acting independently, you should be cautious of conflicts of interest because the decisions of a journalist should not be influenced by outside parties.

Lastly, you must be accountable and transparent. Ethical journalism means taking responsibility for one's work and explaining one's decisions to the public $[1,2]$. This is often seen when news publications issue corrections to a previously ran story. By doing so, journalists maintain their integrity and build trust among their audiences. In the figure below, results from Pew Research indicates that the public's support of the media's watchdog role is changing along partisan lines. Of note, the number of individuals who have become cynical about the media's watchdog role is extremely split in the wake of the election of Donald Trump. Now, $89 \%$ of Democrats support the watchdog function, but only $42 \%$ of Republicans remain trustful.

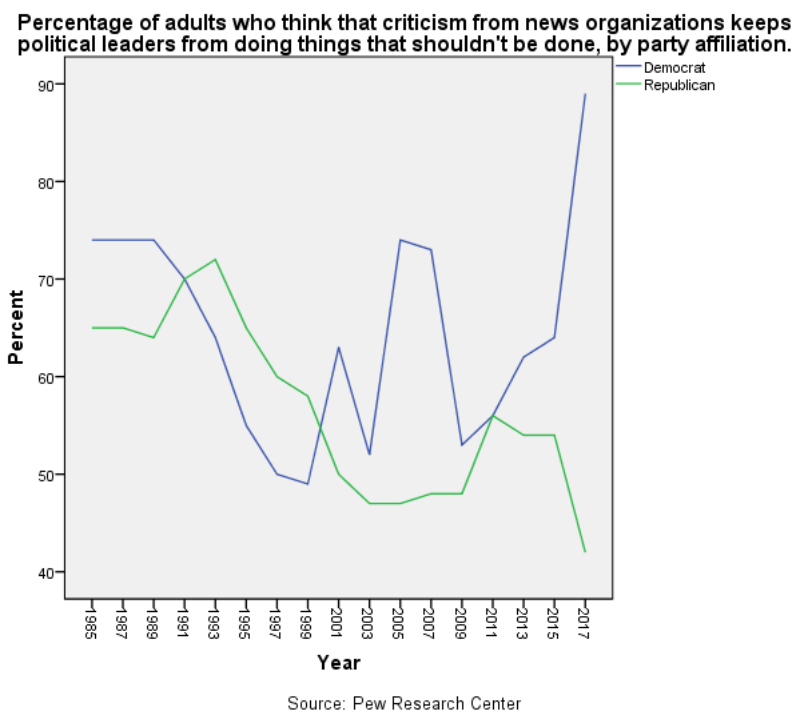

Figure 1. Public Trust in The Media's Warchdog Role

\section{Conflicts with Ethical Reporting}

\subsection{Yellow Journalism}

During the late 1890s, a new form of journalism was introduced. The term "yellow journalism" was coined to describe a type of news that was over-exaggerated, and easily taken out of context. Despite its sensational nature, in 1898, yellow journalism was a contributing factor that sparked the beginning of the Spanish-American War.[3]

Craig Carey explores how the use of telegraphy played an important role in yellow journalism. During the late 1800s, some newspapers were able to exploit and manipulate information as it was sent through the telegraph [4]. During that time, newspapers like the World and the Journal created an ongoing spectacle of war news as they attempted deliver breaking news events. The birth of the internet has increased the reach that news can accomplish. If yellow journalism was able to initiate a war in its time, image what can happen in today's internet dependent society.

\subsection{Checkbook Journalism}

Sometimes news sources try to solicit payments in exchange for their information. When a journalist pays for information, it is referred to as "checkbook journalism." It is often discouraged, mainly because it makes the source's intent questionable. It leaves me to wonder if they are sharing information with 
news reporters because they have legitimate reason, or are they simply seeking some form of monetary gain? In some instances, networks try to outbid each other to obtain information. There have been instances when major news networks like CBS, have paid more than $\$ 20,000$ for the rights to video footage of a crash.

Overall, checkbook journalism leaves reason to question the motives of news sources that ask for money. It can also complicate sound and ethical judgement of the reporter. Reporters should always err on the side of caution when they are paying for information. They should also disclose to the public when they do pay for information.

\subsection{Citizen Journalism}

December 2004, marks the dawn of what is now referred to as citizen journalism. After the South Asian tsunami, citizens and vacationers began reporting their personal accounts of events in real-time. They would record video on cell phones, camcorders, and digital cameras. Despite its amateur nature, it became a new way of getting real images to the public.[5] This type of reporting became a new way of documenting events from a ground view. Citizens would often post in blogs and share their videos on social media outlets like Flickr.com or Moblog.co.uk.

In the years to come, citizen journalists would report on other events like the London bombings, and Hurricane Katrina. This put news organizations in an unfamiliar position. Professional journalists now finding themselves reliant on footage from amateurs to enhance their ability to convey a news story.

During catastrophe, citizen reporting can be beneficial, but in other scenarios it can be misleading. For example, in 2011, West Valley Mayor Mike Winder confessed to falsely reporting as a citizen under the name of Richard Burwash. He was not happy about the way the media was portraying his town and he decided to do something about it. He began to promote his town by writing positive news stories as a citizen journalist.[6]

\subsection{The Colbert Effect}

The Colbert Effect is an interesting concept in relation to journalism. Comedian, Stephen Colbert has found a clever way to fuse news with satire. Over time, it has evolved into a powerful format of news. It entertains and engages the public while communicating political messages.[7] So, does this mean that by definition, Stephen Colbert is a news journalist? Considering the hard work that goes into earning a journalism degree, I would say no. In fact, that's a big no! Faina (2013) argues that Colbert is a journalist, because he is operating under a journalistic banner.

While I disagree with Faina, I can't ignore that there is a unique relationship between public political perception and Colbert's satirical delivery. In his delivery, there is usually a nugget of truth wrapped with layers of creativity, humor, and satire. What's interesting is the fact that many people believe that what Colbert says is reliable news.

\subsection{The Rise of Twitter}

Micro-blogging websites like Twitter have become popular over the years. It's a fast way of communication that can send messages instantly. Interestingly, studies have shown that people between the ages of 35 and 49 are more likely use Twitter.[8] There are other micro-blogging sites that exist, but for this research, I will focus on Twitter, because it is Donald Trump's frequent site of choice.

Between May 1, 2017 and May 11, 2017, there were ten occasions when Donald Trump sent tweets about fake news and fake media. During that time, he had 29.1 million followers (@realDonaldTrump, 2017). As of December 2017, his followings show an increase to 44.2 million. If his negative comments towards the media are reaching millions people, I question how many people are being influenced him. "It is finally sinking through. 46\% OF PEOPLE BELIEVE MAJOR NATIONAL NEWS ORGS FABRICATE STORIES ABOUT ME. FAKE NEWS, even worse! Lost cred," Trump tweeted in October 2017 (@realDonaldTrump, 2017).

In the same month, he also tweeted, "Wow, so many Fake News stories today. No matter what I do or say, they will not write or speak truth. The Fake News Media is out of control" (@ realDonaldTrump, 2017).

Another critical question to ask, is what exactly is fake news to Trump? It seems that when the media shares information that is unfavorable to him, he then brands it with a fake news disapproval stamp! As a consequence of this type of agenda setting, the perception of media is changing, and he is a leading participant.

\section{Analysis}

\section{The Problem}

The media are responsible for holding governmental officials accountable. Their role is to serve in a "watchdog" capacity. This helps to ensure that laws are being upheld and to prevent corruption. On January 20, 2017, Donald Trump was sworn into office to serve as chief executive of the United States. He took an oath to preserve, protect, and defend the Constitution of the United States.

When President Trump undermines the significance of our governmental hierarchy, he does a great disservice to the American public. It appears that he has a lack of respect and consideration for the freedom of the press that was put in place by our country's founding fathers. On the other hand, history shows that journalists do make mistakes. They are by no means exempt from accountability. Journalists should exemplify the same moralistic behaviors that are expected from our governmental politicians.

\section{Method}

To conduct my research, I examined various forms of historical data and made use of available secondary data. My goal was to look deeper at the effects of President Trump's rhetoric and negative feelings towards the media, to compare them to 
historical events that display similar behavioral patterns, and to zero in on exactly what he considers fake news.

\subsection{Nixon and Trump Nixon}

In 1972, the Nixon and the Watergate scandal would serve as another illustration of the ethical responsibilities of the press. Through the investigative reporting of reporters Bob Woodward and Carl Bernstein, they were able to uncover espionage within the United States government. The result would conclude with the resignation of President Richard Nixon.[9]

President Nixon was not secretive about his disapproval of the media, and often took personal offense to news reports written about him. Other presidents in the past have had a history of being at odds with the press, but Nixon was the first to go to the lengths of waging a war against press freedoms. Rather than singling out individual journalists he did this by attacking the media as a whole, he would make attempts to discredit their credibility and even intimidate publishers.

After his death in 1994, audio tapes were released that Nixon recorded while serving in office. In these tapes, you can hear his uncensored distaste for the media and even admissions of lawlessness. "We're up against the enemy, a conspiracy. They're using any means. We are going to use any means. Is that clear? I don't give a shit about the law," said Nixon. He also shared harsh criticisms towards some wellrespected names in the media, "Reasoner's bad, the whole goddamn bunch. Chancellor's bad. Cronkite's bad, Rather's bad. It's awful.'’[10]

In an almost mirrored fashion of the Trump administration, Nixon's rhetoric caused the public to be weary of news entities. Prior to the Watergate scandal, the public opinion of journalists was on a decline. When the news broke about Watergate, citizens grew a sense of appreciation and began to view journalists as heroes. Journalist, Samuel G. Freeman recalls the attitudes towards the media during this time. He was still in college, but he remembers how journalists like Woodward and Bernstein made news reporting look cool, and courageous.[11]

\section{Trump and Fake News}

The term "fake news" is commonly expressed in recent times. It's has gained so much popularity, it even has its own hashtag. People use the term to describe information that is purposely published despite its falsities. Despite the term's new prevalence, fake news has been around for quite some time.[12] This type of misinformation can be damaging, and it is the polar opposite of what ethical news reporting is. The primary role of a journalist is to keep the public informed.

Ironically, President Trump takes credit for coining the popular phrase. Although this is not true, we can look at his behavior on Twitter and see that he does in fact use the term on a regular basis. By using this type of rhetoric, citizens have become more leery and unsure of what to believe. In the table below, from a poll conducted by Pew Research in December of 2016, 64 percent feel that fake news is causing a great deal of confusion.[13]

Table 1. Percent of U.S. adults who say that fake news has caused some level of confusion about the basic facts of current events.

\begin{tabular}{lc}
\hline Level of Confusion & Percent \\
\hline A Great Deal & $64 \%$ \\
Some Confusion & $24 \%$ \\
Not Much/No Confusion & $11 \%$ \\
\hline
\end{tabular}

Fake news would not be as big of a problem if the presence of hosting sites were not available to disseminate its false messages. CNN correspondent, Isa Soares, reported on a fake news operation in Veles, Macedonia. She speaks with a 24-year-old college dropout who only identified himself as Mikhail. He admits creating fake news articles on Facebook during the 2016 presidential elections. By utilizing Facebook, he creates fake user profiles and manipulates U.S. citizens with fabricated news stories.[14] His destructive behavior is solely motivated by money. He points out that he makes around \$2000 to \$2500 a day, whereas most people in his town usually average about $\$ 426$ a month. By using advertising services that pay each time a user clicks onto their content, he is able to cash.

He is determined to repeat his prior fake news tactics again in the 2020 election, but it may not be as easy as before. Since the 2016 election, Facebook has begun to crack down on fake news sites like Mikhail's. There has also been a rise in fact-checking websites like Politifact.com, Snopes.com, and FactCheck.org. Their websites are designed to help news consumers determine the accuracy of trending news stories.

Research conducted by Pew shows that only 39 percent of U.S. adults feel confident in their ability to recognize fake news.[13] This justifies the need for such fact-checking sites, and need for companies like Facebook, to continue to find ways to deter fake news from being shared on their sites.

\subsection{Examples of Nixon and Trump Statements}

The following quotations from White House recordings of President Richard M. Nixon and tweets from President Donald J. Trump show deliberate attacks on the media. In both cases, a significant scandal (Watergate for Nixon and the Bob Mueller investigation in the case of Trump) was being played out in the media.

\section{Nixon}

"Never forget, the establishment is the enemy. The professors are the enemy. The press is the enemy. Write that on the blackboard 100 times, and never forget it."

"This is treasonable action on the part of the bastards that put it out." 
"You must keep up the attack on the media. You've got to keep destroying their credibility."

"Look, if we went and fired up the whole White House staff, that isn't going to satisfy these goddamn cannibals. Who are they after? Halderman or Ehrlichman, or Dean? They're after me, the president. They hate my guts!"

\section{Trump}

"The Fake News Media has never been so wrong or so dirty. Purposely incorrect stories and phony sources to meet their agenda of hate. Sad!"

"The Fake News Media hates when I use what has turned out to be my very powerful Social Media - over 100 million people! I can go around them."

"With all of its phony unnamed sources \& highly slanted \& even fraudulent reporting, \#Fake News is DISTORTING DEMOCRACY in our country!"

"After 200 days, rarely has any Administration achieved what we have achieved..not even close! Don't believe the Fake News Suppression Polls!"

"The Fake News Is going all out in order to demean and denigrate! Such hatred!"

Both presidents made statements alleging that the press was out to get them and accused them of making up stories. However, while Nixon's statements were made in White House meetings, Trump has no qualms about making his claims public through social media. And his claims seem to be having an effect among Trump loyalists. As Table 2 shows, Republicans and Democrats are deeply divided over how fairly Trump is treated by the media, with Republicans being far more likely to believe that the media is reporting unfairly. ${ }^{1}$

Table 2. In general, do you think the media coverage of Donald Trump has been:

\begin{tabular}{lccc}
\hline Response & Democrat & Independent & Republican \\
\hline Too positive & $18 \%$ & $6 \%$ & $5 \%$ \\
Too negative & $18 \%$ & $33 \%$ & $70 \%$ \\
About right & $52 \%$ & $30 \%$ & $15 \%$ \\
Not sure & $13 \%$ & $31 \%$ & $9 \%$ \\
\hline
\end{tabular}

This serves to deepen political polarization and public distrust of the media. Ironically, even as Trump claims that subscriptions are falling at mainstream outlets like New York Times, Washington Post, and CNN, the data do not bear out this contention. Since the 2016 election, digital subscriptions to The New York Times have increased ten-fold.[15]

\footnotetext{
${ }^{1}$ Source: YouGov poll, May 11, 2017
}

\section{Conclusion}

By looking at statistics and social norms, we can determine that Donald Trump has played a significant role in altering the views that Americans have on the media. It is important to remember the importance of freedom of the press and why it was originally established. For the sake of democracy, it is imperative that journalists continue to do their work in an ethical manner even when they don't have the public's trust. Trump draws upon this distrust for his own political advantage.

After reviewing and comparing data, we can conclude that the unhealthy relationship and views of President Trump has a definite effect on the public view. The danger of this is troubled rapport, is that the public is at a disadvantage. They are left with feelings of uncertainty and distrust of our county's leaders and media. Further, Trump is able to capitalize on the levels of partisan hostility in our society to paint the media as dishonest in order to divert attention away from a White House in crisis. On the contrary, the media has remained steadfast in continuing their work by holding those with power accountable.

\section{References}

[1] Fred Brown. Journalism Ethics: A Casebook of Professional Conduct for News Media. Marion Street Press, 2011.

[2] SPJ. Spj code of ethics. https: / / www.spj.org/ ethicscode. asp. Accessed: 2017-04-07.

[3] A. Tompkins. Aim for the heart: write, shoot, report and produce for tv and multimedia.u.s. diplomacy and yellow journalism, 1895-1898. https://history.state.gov/milestones / 1866-1898/yellow-journalism. Accessed: 2017-04-27.

[4] Craig Carey. Breaking the news: Telegraphy and yellow journalism in the spanish-american war. American Periodicals: A Journal of History \& Criticism, 26(2):130-148, 2016.

[5] J.D.H. Downing. Citizen Journalism. Sage, 2010.

[6] A.P. Mayor used alias to promote town. http: / /www. nytimes.com/2011/11/13/us / utah-mayor-promoted-town-using-alias. html. Accessed: 2017-04-27.

[7] Joseph Faina. Public journalism is a joke: The case for jon stewart and stephen colbert. Journalism, 14(4):541$555,2013$.

[8] Paul Farhi. The twitter explosion: whether they are reporting about it, finding sources on it or urging viewers, listeners and readers to follow them on it, journalists just can't seem to get enough of the social networking service. just how effective is it as a journalism tool? American journalism review, 31(3):26-32, 2009. 
[9] W.E. Porter. Assault on the media: the Nixon years. University of Michigan Press, 2010.

[10] P. Kunhardt and P. Schopper. Nixon by nixon: In his own words (video file). https://www.youtube.com/ watch? $=$ gi 0 jP 4 CBsc0. Accessed: 2017-01-11.

[11] S.G. Freedman. Letters to a young journalist. New York, 2011.

[12] Joanna M Burkhardt. History of fake news. Library Technology Reports, 53(8):5-2, 2017.

[13] M. Barthel, A. Mitchell, and J. Holcomb. Many americans believe fake news is sowing confusion. http://www. journalism.org/2016/12/15/ many/americans/believe/fake/news/is/ sowing/confusion. Accessed: 2016-08-12.

[14] I. Soares and F. Davey-Attlee. The fake news machine: Inside a town gearing up for 2020. http://money.cnn.com/interactive/ media/the-macedonia-story. Accessed: 2017-09-16.

[15] M. Belvedere and M. Newberg. New york times subscription growth soars tenfold, adding 132,000, after trump's win. https://www.cnbc.com/2016/ 11/29/new/york/times/subscriptions/ soar/tenfold/after/donald/trump/wins/ presidency.html. Accessed: 2017-11-19. 